\title{
Synthesis of Acetophenones via Regioselective Arylation of Vinyl Ethers
}

\section{Key words}

Heck reaction

acetophenones

aryl halides

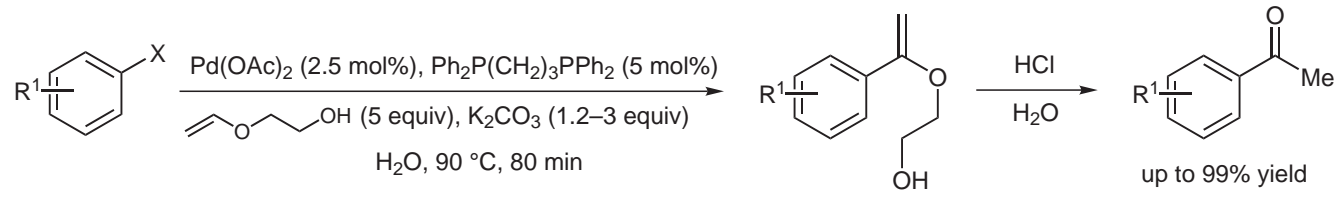<smiles>COc1ccc(C(C)=O)cc1</smiles>

$88 \%$<smiles>COc1ccccc1C(C)=O</smiles>

$84 \%$<smiles>COc1ccc(C(C)=O)cc1</smiles>

$91 \%$<smiles></smiles>

$61 \%$<smiles>CC(=O)c1ccsc1</smiles>

$73 \%$<smiles></smiles>

Significance: This interesting and elegant protocol for the Heck arylation reaction in water is also a quite synthetically useful method for the mild preparation of acetophenones from aryl halides. The reaction is usually completely regioselective and affords high yields of products after the hydrolysis. Functional groups and ortho-substituents in substrates are well tolerated. This method can also be applied to some aryl chlorides and heteroarenes.
Comment: Hydroxyethyl vinyl ether is relatively inexpensive and has been used for the conversion of aryl halides or sulfonates into acetophenones. A similar arylation reaction with an aryl triflate (in MeCN) was applied by the same group for the synthesis of new HIV protease inhibitors (A. Arefalk, J. Wannberg, M. Larhed, A. Hallberg J. Org. Chem. 2006, 71, 1265). Electron-poor heterocycles (pyridines) are poor substrates, while thiophene gives very good results. 